DOl: https://doi.org/10.24297/jssr.v16i.8904

\title{
Effect of Social Capital on Firm Performance: An Empirical Study of Small Enterprises in Sri
}

\section{Lanka}

\author{
Menike L.M.C.S.
}

Department of Accountancy and Finance, Faculty of Management Studies, Sabaragamuwa University of Sri Lanka, Belihuloya. Sri Lanka

email: Imcsmenike@gmail.com

\begin{abstract}
The purpose of this study is to examine the impact of social capital on the performance of Small Enterprises (SEs) in an emerging economy, Sri Lanka. The study adopts a survey design and cross-sectional data collected by administering 200 questionnaires conducting face to face interviews. The social capital was measured by three dimensions namely, structural, relational, and conative social capital. The data were analyzed using Partial Least Squares-Structural Equation Modelling. The results show that structural and cognitive social capital had a positive significant impact on the performance of SEs while relational social capital had demonstrated a negative statistically significant impact on the performance of SEs. This implies that the managers of SEs emphasize the social capital as a means to a source of finance and resources and access to business and market information by maintaining close ties with the stakeholders to achieve a competitive advantage. The findings will be useful for the owners/managers of SEs who should share their knowledge, opportunities, and resources with their suppliers, customers as well as employees of the organization such that they should try to share their goals and achieve success together with parties who are related and interested in the business.
\end{abstract}

Keywords: Firm Performance, Small Enterprises, Social Capital, Sri Lanka

\section{Introduction}

The social capital which is the binding force that holds institutions has increasingly attracted substantial consideration of many scholars in developed and developing country studies (Cantner \& Stuetzer, 2010; Ndofor \& Priem, 2011; Patel \& Terjesen, 2011; Brink, 2011: Bradley et al., 2012: Kipchirchir (2014): Agyapong et al., 2017). Bourdieu (1983) defines social capital as the aggregate of the actual or potential resources that are linked to the possession of a durable network of more or less institutionalized relationships of mutual acquaintance and recognition. It is defined as the entire resources a firm accrues through its durable network of relationships with other firms (Nahapiet \& Ghoshal, 1998). This social capital can as well be referred to as the social connections through which entrepreneurs can obtain tangible and intangible assets necessary for business performance (Dai et al., 2015). The resources informal entrepreneurs can access via their network and social connections enable them to identify business opportunities (Bhagavatula et al., 2010) and mobilize human and financial resources (Batjargal, 2003).

Social capital has been viewed from both content and process perspectives and three dimensions of social capital are identified structural, cognitive, and relational from the content perspective (Nahapiet \& Ghoshal, 1998; Pearson, Carr, \& Shaw, 2008). The structural dimension is necessary for the existence of relational and cognitive dimensions, whereas the cognitive dimension is necessary for the existence of the relational dimension.

The structural dimension is defined as the overall pattern of connections between individuals (Burt, 2000). It also refers to the structure of the social network (Bhagavatula, 2009). A network can be defined as an interpersonal relationship between people as a means of communicating information. The relational dimension is defined as a personal relationship that people have developed with each other and these relationships are the sources for fulfilling the social needs (Nahapiet \& Ghoshal, 1998). Further, trust is an important factor of the relational dimension as it ensures these social interactions (Chow \& Chan, 2008) The cognitive dimension can be defined as the resources which provide share representation, interpretation, and systems of meaning. According to the Chow \& Chan (2008) resources are increasing, understanding 
between parties. This dimension has represented properties like a common language, common understanding, norms of action in a social setting (Priyanath \& Premaratne, 2015). The cognitive dimension also can be included attributes like shared language, shared narratives, common perspective, and communal congruence or generally agreed-upon meanings (Nahapiet \& Ghoshal, 1998). The stability, closure, interdependence, and interaction are the four dynamic factors from the process perspective which enhance the creation of social capital and foster its creation and evolution (Bourdieu, 1983; Coleman, 1990; Misztal, 1996; Nahapiet \& Ghoshal, 1998; Arregle et al., 2007).

Social capital among the members of an organization enhances their ability in sharing knowledge and transferring ideas among each other and social capital improves the ability of businesses in gathering resources that could improve their performance (Florin et al., 2003). Rooks, Szirmai, \& Sserwanga (2009) state that entrepreneurs and firm owners and managers must develop strong ties with social, business, and personal relationships to be benefited completely from social networks.

Leana \& Pil (2006) conclude that there is a positive relationship between social capital and corporate performance, while Geletkanycz \& Hambrick (1997) report that the relationship networks (or social capital) are important sources of information and knowledge that complement the experiences of employees, which in turn affect the organization's performance. Social capital improves the performance of MSBs by enhancing the cost reduction of transactions, which eventually generates better efficiency results (Fafchamps \& Minten, 2002) and suggest that organizations with high social capital would report higher firm productivity than organizations with low social capital do.

Scholars have investigated the relationship between social capital and organizational performance (Felicio et al., 2014; Clarke et al., 2016; Pratono, 2018), while Stam et al. (2014) examined the effects of an entrepreneurs' social capital on small firm performance. Social capital is an important factor in the organization because it is benefited to the organization's knowledge \& opportunities for the organization to understand the network structure of the organization (Celestini, Gavronski, \& Kaynak, 2013). Social capital helps to get an advantage from the financial resource, as well as increases the efficiency of activities in the organization. As a result of that social capital can be identified as economic assets (Celestini, Gavronski, \& Kaynak, 2013). Social capital shows how people work with others, the effect of human interaction within the relationship as well as how individuals are related to the network or relationship (Muniady et al., (2015). They further state that building strong social capital within the organization or network will be useful to confirm the relationship between buyer and supplier of a company thereby increase the sales value of the company and increase the profit as well.

Social networks are pretty essential for SMEs in the era of continually developing and emerging economies (Le Van, Nguyen, Nguyen \& Simioni, 2018). Asian markets are intensive networking (Hitt, Lee \& Yucel, 2002) and in the framework of a developing economy such as Sri Lanka, it is immensely important for SEs to depend on their social capital. Moreover, the use of SC is also of particular importance to SEs because of the skewed and corrupt design of their target markets (Le Van et al., 2018). However, scholars have given a little attention to investigate the influence of social capital on firm performance in SEs particularly in Sri Lanka and this study fill this gap by addressing the research question; how does social capital influence the performance of SEs?

\section{Theoretical Background and Research Model}

\section{Social Capital Theory}

The SC can be defined as "the value of the relationship that has three characteristics; trustworthiness, norms, and information transfer" (Coleman, 1988). Putnam (1995) defines Social capital as the features of an organization like networks, norms, and trust, which can be increased the efficiency of society. Social capital is the resources that can be invested in the organization for future benefits like quick access to information, resources, and new opportunities in the market (Burt, 2000). The direct benefit of social capital is giving easy ways to access information and increased quality, relevance, and timeline of information (Alder \& Kwon, 2002). Social embeddedness allows firms to exchange information and resources among people (Uzzi,1996). According to (Burt, 2000) social capital acts as an outflow of information and the network is 
useful to access information for the firm. The firm can catch the information via the network. Social capital can be considered as a source of the information (Priyanath \& Premaratne, 2015). Nahapiet \& Ghoshal (1998) states that social capital is useful to exchange information as well as access to information, when at the right time, in the right places. If the business has a high level of social capital, they can get information high level of correctly \& effectiveness. Efficiency \& Effectiveness of business activities can be increased via social capital. The structure of social interaction helps to the adopted vision of the organization's common language interpersonal trust between people. SC is the resources that generate from the pattern of relationships, value of relationships among individuals and common understand among individuals (Chow \& Chan, 2018; Abban et al., 2013).

Nahapiet \& Ghoshal, (1998) identify three dimensions of social capital; structural, relational, and cognitive. The structural dimension emphasizes the level of connection and closure amongst social network members, the relational dimension emphasizes the strength of these social relationships, and the key factors here are trust and trustworthiness, while the cognitive dimension emphasizes the shared values, norms, and beliefs existing amongst the social network.

\section{Conceptual Framework and Hypotheses}

Social capital (SC) encompasses "the sum of the actual and potential resources embedded within, available through, and derived from the network of relationships possessed by an individual or social unit" (Nahapiet \& Ghoshal, 1998). Scholars suggest that it could be divided into triple dimensions (Adler and Kwon, 2002; Aladwani, 2002; Chang et al., 2011) namely, structural, relational, and cognitive social capital.

The structural dimension deals with the connection and closure amongst social network members (network ties) and is measured using the network size, density, and strength of the network. The strength of network ties is a linear combination of the amount of time, the emotional intensity of the intimacy, and the reciprocal services which characterize each tie. Network strength is connecting people and enhancing the relationship between them. Bhagavatula (2009) states network size is the number of relationships that a person is directly connected to. Premaratne (2002) describes that network size is the number of people with whom they dealt with in business activities and supports such as discussions their plans for running a business, information, cash, moral support, and any other resources. Network size means the number of actors in a network (Bouzdine \& Lorgnier, 2004). Network density is the average strength of the connection between actors. Density is one of the forms of network closure (Bouzdine $\&$ Lorgnier, 2004). Dense network structure defines as a focal member who knows and has contact with many members in the network (Bhagavatula, 2009). Stone (2001) defines network density as; the extent to which network members are in each other's networks. Thus, network density implies that the percentage of close relationships within the total number of possible relationships among others (Batjargal, 2005). The relational dimension emphasizes the strength of these social relationships, and the key aspects here are credibility and benevolence.

The cognitive dimension emphasizes the shared vision, shared language, shared knowledge, shared recourses, and shared opportunities existing amongst the social network. The shared vision is the common understanding between entrepreneur and network members about the importance of sharing similar ambitions like achieve success, shared language can be defined as the common understanding between entrepreneur and exchange partners about the use of understandable communication pattern, shared knowledge is the common understanding between entrepreneur and network members about the importance of sharing knowledge, shared resources are the common understanding between entrepreneur and network members about the importance of sharing resources and shared opportunity is the common understanding between entrepreneur and network members about the importance of sharing opportunity. The business performance is measured as the number of workers, total assets, total product volume, the average number of customers, average sales volume, and profitability of SEs (see Figure 1). Thus, the study examines the impact of social capital on the performance of SEs in Sri Lanka and proposes the following model. 


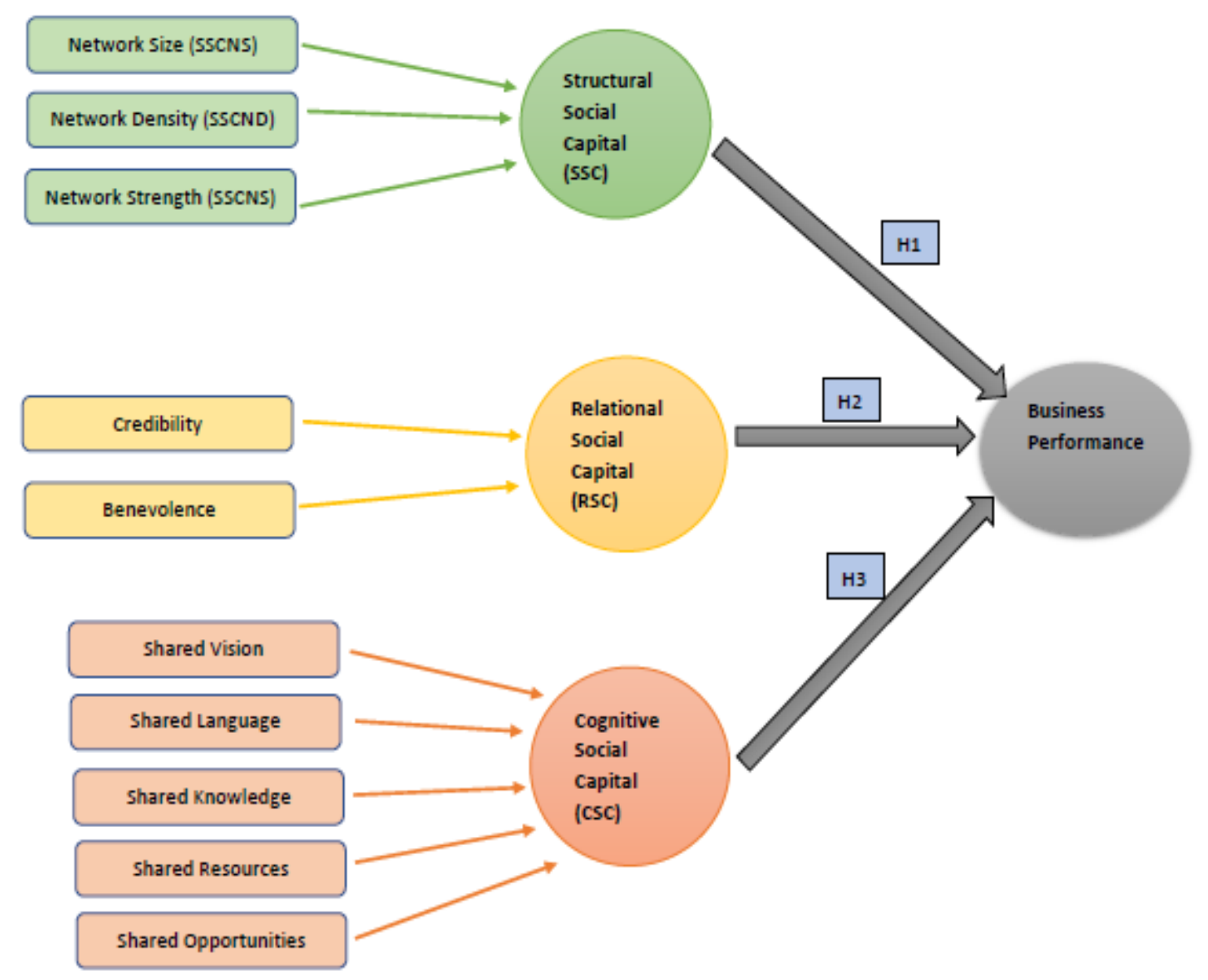

Figure 1: Conceptual Framework

\section{Structural Social Capital:}

Structural social capital can be identified as a collection of network ties, network configuration, and network appropriability (Nahapiet \& Ghoshal, 1998). According to Coleman (1990), the transfer of information within the firm is useful to build an interconnection between people. Network ties mean a connection between people in the firm and it is caused to the success of a firm's activities because the workers have knowledge among them $\&$ they know them. It can be formal interaction or informal interaction. Structural social capital refers to the pattern of the connection between people in the firm and outside the firm. The pattern of the interconnection between people is useful to develop interpersonal trust between people and it is determined the network strength between people (Mark, William, \& James, 2009). On the other hand, it can be oral, written, or electronic interconnection between the people of a firm whatever among these connections, it is important to the organization for their success. Many factors affected the network interconnection such as structural holes, centralization, and density (Mark, William , \& James, 2009). Strong network seizing can be affected by the flow of information of the company (Nahapiet \& Ghoshal, 1998).

The main aspect of the structural social dimension is network ties between people of the network. Network ties can be measured by using network density, connectivity, and hierarchy number of contracts, diversity of contract, configuration, and network stability (Celestini, Gavronski, \& Kaynak, 2013). It is based on the size of network density and the strength of the network (Nahapiet \& Ghoshal, 1998). Interaction between people is the most important aspect of the structural dimension. Interaction can be made via meetings, teamwork, emails, or discussion with people (Aslam, Shahzah, Syed, \& Ramish, 2013). Uzzi (1996) proposes that the network relationship among firms are share information and share resource among them. The structural social capital can be identified as the overall pattern of connection between people. Interconnection between people and the groups are useful to gather knowledge from others. They can use 
physical and electronic methods to share knowledge with others, the main measurement of the structural social capital is network complexity and the density (Priyanath \& Premaratne, 2015).

Structural social capital is structural networking among people with alignment relationships and binding, forming and matching networks can be identified as structural networks and activities of the company will be effective when the people have effective understand between those people and build a good interpersonal relationship between people within the organization (Soesanto \& Setiadi, 2017). Moreover, a network can significantly influence the flow of information and assistance in a network. If the business has strong relationships, it facilitates to access business and market information and increases competitive advantage as well as revenue and profit of the business (Ozigi, 2017). Thus, it is formulated the following hypothesis.

$\mathrm{H} 1$ - There is a significant positive relationship between structural social capital and firm performance

\section{Relational Social Capital:}

Relational social capital refers to trust, norms, and obligation between the people (Nahapiet \& Ghoshal,1998). Granovetter (1983) proposes that strong network ties cause to build interpersonal trust, reciprocity between individuals. If the company has high interpersonal trust between interested parties of the organization, it increases the performance of the organization and the value of the activities which are done by the other parties (Mark, William, \& James, 2009). According to Mishira (1996) intention, openness, competence, and reliability are required to build interpersonal trust among people within the organization or outside the organization and trust between people who are outside the organization such as suppliers, customers or any other interested parties about the organization is essential.

Relational social capital shows types of relationships which social actors or units develop over time and it focuses on the characteristic of the relationship between the people (Celestini, Gavronski, \& Kaynak, 2013). Relational social capital also shows the trust between people via social interaction (Chow \& Chan, 2008). When we consider the relationship, trust is an important factor (Alder \& Kwon, 2002).

Relational social capital is considered as assets for the firm (Priyanath \& Premaratne, 2015). As per Granovetter (1973) relational social capital is a relationship that is indicated by a high level of confidence. Thus, relational social capital is often connected with trust. Jones \& George (1998) state that relational social capital helps to exchange resources, improve communication, foster cooperation between people. It can be built a high level of relational social capital and develop teamwork and improve organizational functioning company (Soesanto \& Setiadi, 2017). Social capital can raise trust, honesty, and integrity which helps to access more information and capital and get a competitive advantage (Ozigi, 2017). There was a statistically significant positive correlation between relational social capital and growth of medium enterprises in Kenya (Okello, 2017). The key aspects of relational social capital are trust, norms, obligations, expectations, and identification (Nahapiet \& Ghoshal, 1998). Thus, the study uses inter-personal trust as a key dimension to represent a relational form of social capital and proposes the following hypothesis.

$\mathrm{H} 2$ - There is a significant positive relationship between relational social capital and the firm performance

\section{Cognitive Social Capital}

Cognitive social capital refers to mutual understanding among people and the shared knowledge, vision, and opportunities among people of the firm and other parties (Nahapiet \& Ghoshal, 1998). Shared narratives are useful to discuss problems, exchange resources, transfer information, and knowledge effectively among people and it can continue the effective communication between people through shared language. Not only that cognitive social capital gives a common vision to people which is helpful to do an activity to achieve one vision in the future. Because of that both shared language and shared narratives help to understand among people and the organization (Mark, William , \& James, 2009).

The cognitive dimension shows the sharing of vision, resources, language, and knowledge between the people in the network and it is helpful to a common understanding about the people in the network (Aslam, Shahzah, Syed, \& Ramish, 2013). Cognitive social capital can be identified as properties such as common 
language, common vision, or shared goals and opportunities among the network (Tasai \& Goshal, 1998). Cognitive social capital arises as a result of sharing the same practices, to learn skills and knowledge (Priyanath \& Premaratne, 2015). Nahapiet \& Ghoshal (1998) propose the shared language, shared narrative as a measurement of cognitive social capital.

Cognitive social capital is the ability of individuals within the organization to understand each other and mutual understand between people facilitated to exchange of ideas and sharing stories that people can discuss the problems, transfer ideas, share knowledge and help each other very easily (Soesanto \& Setiadi, 2017). According to Weich (1995) cognitive social capital helps to improve language proficiency and communicate with others. Knowledge sharing helps people who are related to the organization to continue the effective communication skills. Besides, sharing the ideas and the story leads to increase understanding between people relating to the organization (Soesanto \& Setiadi, 2017). As a result of that the organization can anticipate and predict the activities of co-workers and facilitating the use of input from various, members, and any changing conditions (Soesanto \& Setiadi, 2017; Uzzi, 1996). The cognitive social capital plays a significant role to get a business advantage for business better than competitors and to generate revenue and overall business performance (Ozigi, 2017) Thus, the study proposes the following hypothesis.

$\mathrm{H} 3$ - There is a significant positive relationship between cognitive social capital and the firm performance.

\section{Materials and Methods}

The study attempted to investigate the effect of social capital on the performance of SEs. The deductive approach has been utilized with a quantitative method. The unit of analysis is the owners/managers of manufacturing SEs in Sri Lanka. The Department of Census and Statistics (DCS) in Sri Lanka defines SEs as 'establishment with 5 - 24 persons engaged" and the same definition was used to select SEs to carry out the survey. First, the study selected only the enterprises classified under the manufacturing category as the sample frame. As per the Economic Census in 2013/2014, there were 14,185 industries which belong to the category of manufacturing establishments (SMEs) out of which 13160 represent small businesses. Next, using the sample frame (13,160 of SEs), 200 SEs were selected by following Kline (2011) the minimum sample size criterion required to analyze the data using Structural Equation Modelling (SEM). Then, the sample is distributed according to the percentage share of the SEs located in each district and determine the number of firms to represent all the districts in Sri Lanka. Next, SEs of each district were listed according to the ISIC category and the sample was selected using a stratified sampling method to represent all the manufacturing industrial divisions.

The study applied a survey method to collect data, a structured questionnaire was constructed and administered. Proper care has been paid to design the questionnaire using the first step to identify items by reviewing existing literature under each construct using simple and clear words, the logical and sequential arrangement of questions with regards to three pillars of social capital and firm performance of SEs. Then, the respondents were required to choose answers on a Likert scale of 7,1-Strongly disagree, 2 - Disagree, 3 - Somewhat disagree, 4 - Neither agree nor disagree, 5 - Somewhat agree, 6 - Agree, 7 Strongly agree. Next, to preserve the validity and reliability of the questionnaire a pilot survey was conducted with $30 \mathrm{SEs}$ and it was verified whether the questions are understandable; whether the instructions are clear and the order of the questions is appropriate and the questions are meaningful. Face to face interview method was used to collect data. Partial least square-structural equation modeling (PLSSEM) was applied to analyze the gathered data and to test hypothesized relationships. The reliability and validity tests and the efficiency of the model have been examined by multi-collinearity issues, $R^{2}$, effect size $\left(f^{2}\right)$, and predictive relevance $\left(\mathrm{Q}^{2}\right)$. The SmartPLS (version 3 ) software was used to analyze data.

The questionnaire was structured into five parts: Section 1 of the questionnaire aimed at collecting general information of the respondents. Section 2 of the questionnaire addressed questions regarding the firm performance measured by using six factors namely, the effect of changes in employees, capital assets, product volume, customers, sales value, and profitability (Priyanath \& Premaratne, 2015). Section 3 of the questionnaire sought to capture structural social capital measured by using three factors namely network size, network density, network strength (Bhagavatula, 2009). Network density was measured as a percentage 
of close relationships within the total number of possible relationships. Network size was calculated by the number of close relationships in different categories of the network which included two categories: first, social networks are formed by family, relations, friends, and neighbors; second, supportive networks comprise buyers and suppliers (Babaei et al, 2012). Evaluating the network size and network density in ratio scale was done by inquiring each respondent to estimate the numbers of persons, he/she has closed connection with and the percentage of close connection out of the potential connections. Section 4 of the questionnaire is devoted to cover the relational social capital measured by the trust (Priyanath \& Premaratne, 2015). Interpersonal trust is a strong, deep, or close association or more people that may range in duration from brief to enduring. In there has a belief which another person is honest and benevolent. Finally, Section 5 covers cognitive social using 5 dimensions, shared vision, shared language, shared resources, shared knowledge, and shared opportunities (Tasai \& Goshal, 1998; Chow \& Chan, 2008). A shared vision can be defined as the common understanding between entrepreneur and network members about the importance of sharing similar ambitions like achieve success. Shared language can be defined as the common understanding between entrepreneur and exchange partners about the use of understandable communication patterns. Shared knowledge can be defined as the common understanding between entrepreneur and network members about the importance of sharing knowledge. Shared resources can be defined as the common understanding between entrepreneur and network members about the importance of sharing resources. Shared opportunity can be defined as the common understanding between entrepreneur and network members about the importance of sharing opportunity.

\section{Results and Discussion}

The study attempted to explore the empirical evidence relating to the effect of social capital on the business performance of SEs in Sri Lanka and gathered data by administering questionnaires amongst 200 owners/managers of SEs. Regarding the personal characteristics of the respondents, 75 percent of participants included in the sample were males. A larger proportion of the respondents (47\%) belonged to the age category of 20-30 while 15 percent are in above 50 age level. Of the 200 respondents' 32 percent were educated up to $\mathrm{O} / \mathrm{L}$ and 50 percent are educated up to A/L. However, 12 percent had obtained a first degree and the least 6 percent are the owners who have educated up to grade 5 . It is evidenced that 72 percent of the owners have got trained compared to the remaining 28 percent who have not got pretraining. A larger portion of the respondents ( $43 \%$ ) have 1-5 years' experience in the field while 24 percent have 5-10 years' experience and 17 percent of owners have 10-20 years' experience in the respective business field. Anyhow, the owners who have more experienced above 20 years are only 16 percent. The results reveal that 80 percent of businesses were started by the current owner of the business

Table 1: Analysis of the First-order Constructs

\begin{tabular}{lllll}
\hline Construct & Indicator Reliability & $\begin{array}{l}\text { Internal } \\
\text { Reliability }\end{array}$ & Consistency & $\begin{array}{l}\text { Convergent } \\
\text { validity }\end{array}$ \\
\cline { 2 - 5 } & Loading & t-statistics & $\begin{array}{l}\text { Composite } \\
\text { Reliability }\end{array}$ & $\alpha$ \\
& & Cronbach's & AVE
\end{tabular}

1. Structural Social Capital

$\begin{array}{llllll}1.1 \text { Network Size } & 1.000 & 1.000 & 1.00 & 1.000 & 1.000 \\ 1.2 \text { Network Density } & 1.000 & 1.000 & 1.000 & 1.000 & 1.000 \\ 1.3 \text { Network Strength } & & & 0.848 & 0.761 & 0.583\end{array}$

$\begin{array}{lll}1.3 \mathrm{~A} & 0.785 & 15.67 \\ 1.3 \mathrm{~B} & 0.761 & 16.83 \\ 1.3 \mathrm{C} & 0.777 & 13.30 \\ 1.3 \mathrm{E} & 0.729 & 9.45\end{array}$


2. Relational Social Capital

2.1 Benevolence

Trust

$2.1 \mathrm{~A}$

0.864

32.505

$2.1 \mathrm{~B}$

0.931

73.505

$2.1 \mathrm{C}$

0.933

76.158

$2.1 \mathrm{D}$

0.726

16.211

$2.1 \mathrm{E}$

0.840

28.131

$2.1 \mathrm{~F}$

0.861

33.373

$2.1 \mathrm{G}$

0.717

15.920

2.2 Credibility

0.952

0.954

0.742

Trust

$\begin{array}{lll}2.2 \mathrm{~A} & 0.772 & 22.563 \\ 2,2 \mathrm{~B} & 0.870 & 37.193 \\ 2.2 \mathrm{C} & 0.873 & 38.532 \\ 2.2 \mathrm{D} & 0.918 & 56.663 \\ 2.2 \mathrm{E} & 0.893 & 43.147 \\ 2.2 \mathrm{~F} & 0.859 & 27.380 \\ 2.2 \mathrm{G} & 0.836 & 24.658\end{array}$

3. Cognitive Social Capital

3.1 Network members share common ambitions that 0.974

0.969

0.846 we all need to achieve success
$3.1 \mathrm{~A}$
0.846
29.620
$3.1 \mathrm{~B}$
0.899
36.868
$3.1 \mathrm{C}$
0.946
68.562
3.1D
0.932
42.753
$3.1 \mathrm{E}$
0.953
61.353
$3.1 \mathrm{~F}$
0.961
96.691
$3.1 \mathrm{G}$
0.894
31.056

3.2 Network members use understandable 0.93 communication pattern which can be easily

0.905

0.733 understand

$\begin{array}{lll}3.2 \mathrm{~A} & 0.876 & 35.180 \\ 3.2 \mathrm{~B} & 0.943 & 86.471 \\ 3.2 \mathrm{C} & 0.941 & 71.887 \\ 3.2 \mathrm{D} & 0.835 & 12.151\end{array}$




\section{$3.2 \mathrm{E}$ \\ 0.651 \\ 8.798}

3.3 They always willing to share their knowledge \& 0.964

0.953

0.845 expertise skill with me

$\begin{array}{lll}3.3 \mathrm{~A} & 0.831 & 16.495 \\ 3.3 \mathrm{~B} & 0.954 & 74.982 \\ 3.3 \mathrm{C} & 0.946 & 52.522 \\ 3.3 \mathrm{D} & 0.942 & 51.157 \\ 3.3 \mathrm{E} & 0.916 & 37.452\end{array}$

3.4 They are willing to share their spaces, machines, 0.968

0.960

0.835 tools and equipment,

vehicles and transportation equipment, \& financial resources with me

$\begin{array}{lll}3.4 \mathrm{~A} & 0.869 & 34.336 \\ 3.4 \mathrm{~B} & 0.916 & 54.521 \\ 3.4 \mathrm{C} & 0.916 & 56.007 \\ 3.4 \mathrm{D} & 0.951 & 69.494 \\ 3.4 \mathrm{E} & 0.949 & 69.241 \\ 3.4 \mathrm{~F} & 0.918 & 42.136 \\ 3.4 \mathrm{G} & 0.819 & 27.310\end{array}$

3.5 They are willing share their new business

0.971

0.965

0.831 opportunities \&Beneficial opportunities they receive with me.

$\begin{array}{lll}3.5 \mathrm{~A} & 0.869 & 30.384 \\ 3.5 \mathrm{~B} & 0.934 & 47.593 \\ 3.5 \mathrm{C} & 0.933 & 51.610 \\ 3.5 \mathrm{D} & 0.938 & 49.318 \\ 3.5 \mathrm{E} & 0.957 & 79.900 \\ 3.5 \mathrm{~F} & 0.905 & 33.529 \\ 3.5 \mathrm{G} & 0.839 & 17.515\end{array}$

Source: Survey data, 2020

The relationship between social capital and SEs performance was evaluated using a two-step approach using PLS-SEM to establish construct reliability and validity of the outer model. First, the measurement model (outer-model) was assessed examining the reliability and validity of the measurement items of constructs. Second, the structural model (inner-model) was assessed to test hypothetical relationships.

Table 2: Discriminant Validity of First-order Constructs (Fornell-Larcker criterion) 


\begin{tabular}{|c|c|c|c|c|c|c|c|c|c|c|c|}
\hline & AVE & 1 & 2 & 3 & 4 & 5 & 6 & 7 & 8 & 9 & 10 \\
\hline Net Density & 1.00 & 1.00 & & & & & & & & & \\
\hline Net Size & 1.00 & 154 & 1.00 & & & & & & & & \\
\hline Net Strength & 0.583 & 135 & .183 & 0.763 & & & & & & & \\
\hline Benevolence Trust & 0.711 & $1.178^{*}$ & -.164 & 4.048 & 0.843 & & & & & & \\
\hline Credibility Trust & 0.742 & .145 & -.116 & -.217 & .708 & 0.861 & & & & & \\
\hline Shared Knowledge & 0.845 & $269^{* \star}$ & $*-.053$ & -.004 & $.595^{* *}$ & $376^{\star \star}$ & 0.919 & & & & \\
\hline Shared Language & 0.733 & $209^{*}$ & -.023 & .000 & $.514^{\star *}$ & $459^{* *}$ & $.810^{* \star}$ & 0.856 & & & \\
\hline Shared Opportunity & 0.831 & $202^{*}$ & -.101 & $1-.005$ & $.598^{* *}$ & $.384^{* \star}$ & $.909^{\star *}$ & $.837^{* *}$ & 0.911 & & \\
\hline Shared Recourses & 0.822 & .093 & -.047 & 7.005 & $.492^{* \star}$ & $355^{* *}$ & $.806^{* *}$ & $825^{\star *}$ & $807^{\star *}$ & 0.906 & \\
\hline Shared Vision & 0.846 & $5.266^{* *}$ & -.084 & $4-.040$ & $.543^{* \star}$ & $359^{* \star}$ & $.915^{\star \star}$ & $.774^{\star \star}$ & $.905^{* \star}$ & $.768^{\star \star}$ & * 0.919 \\
\hline
\end{tabular}

Source: Survey data, 2020

First, it was developed three of first-order endogenous latent variables of structural, relational, and cognitive social capital and assessed using the standardized factor loadings and t-statistics. Table 1 shows standardized factor loadings which were above the minimum threshold criterion 0.7 confirming the indicator reliability of first-order reflective constructs. Further, it shows that all the factor loadings were statistically significant at the 0.05 significance level and confirms strong evidence for indicator reliability of the first order measurement items. The Cronbach's $\alpha$ was higher than the required value of 0.7 and composite reliability was higher than the recommended 0.7 value (Table 1) hence, confirms the convergent validity of the first-order constructs. Average Variance of Extract (AVE) for each construct was higher than the required value 0.5 indicating that each construct can explain more than half of the variance to its measuring items on average. On discriminant validity, none of the inter-construct correlation values were above the square-root of the AVE and satisfied the criterion of the discriminant validity of first-order constructs (Table 2).

Table 3: Analysis of the Second-order Constructs

\begin{tabular}{llllll}
\hline Construct & \multicolumn{3}{c}{ Indicator Reliability } & Internal Consistency Reliability & $\begin{array}{l}\text { Convergent } \\
\text { validity }\end{array}$ \\
\cline { 2 - 6 } & Loading & $\begin{array}{l}\mathrm{t} \text { - } \\
\text { statistics }\end{array}$ & $\begin{array}{l}\text { Composite } \\
\text { Reliability }\end{array}$ & $\begin{array}{l}\text { Cronbach's } \\
\alpha\end{array}$ & AVE \\
\hline 1. Firm Performance & & & 0.918 & 0.883 & 0.738 \\
BP3 & 0.771 & 11.73 & & & \\
BP4 & 0.922 & 55.29 & & \\
BP5 & 0.927 & 58.37 & & 0.566 \\
BP6 & 0.803 & 14.15 & & 0.741 & \\
\hline 2. Structural Social Capital & & 0.722 & \\
Net Dense <- SSC & 0.806 & 3.90 & & & \\
Connectivity $<-$ & 0.694 & 2.28 & & & \\
SSC & & & & & \\
\hline
\end{tabular}




\begin{tabular}{|c|c|c|c|c|c|c|}
\hline \multirow[t]{3}{*}{3.} & \multicolumn{3}{|c|}{ Relational Social Capital } & \multirow[t]{3}{*}{0.901} & \multirow[t]{3}{*}{0.828} & \multirow[t]{3}{*}{0.821} \\
\hline & Benevolence & 0.984 & 3.07 & & & \\
\hline & Credibility & 0.821 & 3.32 & & & \\
\hline \multirow[t]{6}{*}{4.} & \multicolumn{2}{|c|}{ Cognitive Social Capital } & & 0.972 & 0.965 & 0.877 \\
\hline & 5.1 & 0.930 & 57.04 & & & \\
\hline & 5.2 & 0.929 & 66.46 & & & \\
\hline & 5.3 & 0.954 & 66.51 & & & \\
\hline & 5.4 & 0.916 & 59.26 & & & \\
\hline & 5.5 & 0.951 & 74.82 & & & \\
\hline
\end{tabular}

Source: Survey data, 2020

The second-order constructs were developed using latent variable scores of the first-order constructs. Indicator reliability of three endogenous latent variables at the second-order level in the hierarchical model was evaluated. All path coefficients (standardized factor loadings) were well above the threshold value of 0.7 (Table 3). The bootstrapping procedure was conducted to estimate the significance of each path coefficient by examining the t-statistics and all the $t$-statistics were significant at the 0.05 significance level thereby confirms strong evidence for indicator reliability of the second-order constructs. The Cronbach's $\alpha$ was higher than the required value of 0.7 and composite reliability was higher than the recommended 0.7 value which was developed reliably in the second-order constructs. The AVE for each construct was higher than the required value 0.5 and confirms the convergent validity of the second-order construct. The discriminant validity of the second-order constructs showed that none of the inter-construct correlation value was above the square-root of the AVE and satisfied the criterion of the discriminant validity of the second-order constructs (Table 4).

Table 4: Discriminant Validity of Second-order Constructs (Fornell-Larcker criterion)

\begin{tabular}{|l|l|l|l|l|l|}
\hline Construct & AVE & $\begin{array}{l}\text { Business } \\
\text { Performance }\end{array}$ & $\begin{array}{l}\text { Cognitive } \\
\text { Social Capital }\end{array}$ & $\begin{array}{l}\text { Relational } \\
\text { Social Capital }\end{array}$ & $\begin{array}{l}\text { Structural } \\
\text { Social Capital }\end{array}$ \\
\hline $\begin{array}{l}\text { Business } \\
\text { Performance }\end{array}$ & 0.738 & $\mathbf{0 . 8 5 9}$ & & & \\
\hline $\begin{array}{l}\text { Cognitive Social } \\
\text { Capital }\end{array}$ & 0.877 & 0.486 & $\mathbf{0 . 9 3 6}$ & & \\
\hline $\begin{array}{l}\text { Relational Social } \\
\text { Capital }\end{array}$ & 0.821 & 0.165 & 0.575 & $\mathbf{0 . 9 0 6}$ & \\
\hline $\begin{array}{l}\text { Structural Social } \\
\text { Capital }\end{array}$ & 0.566 & 0.230 & 0.154 & 0.121 & $\mathbf{0 . 7 5 2}$ \\
\hline
\end{tabular}

Source: Survey data, 2020

\section{Hypotheses Testing}

The second step of the PLS-SEM analysis is testing the theorized causation of the structural model as suggested by Hair et al. (2014). The structural model primarily assesses the hypothesized causal relationship between exogenous and endogenous latent variables. To evaluate the structural model first, Multicollinearity issues were assessed and calculated VIF and tolerance level with the support of the linear regression option in SPSS. The results indicated that there are no multi-collinearity issues among variables. 
VIF values for the entire path show minimal collinearity, ranging from 1.026 to 1.511 and these values are significantly less than the recommended threshold value of 5.00 . The tolerance levels range from 0.662 to 0.974 exceeding 0.20 which provides strong evidence for the absence of multicollinearity issues between the independent constructs in the structural model (Table 5).

Table 5: Collinearity Statistics

\begin{tabular}{lll}
\hline Model & \multicolumn{2}{c}{ Collinearity Statistics } \\
\cline { 2 - 3 } & Tolerance & VIF \\
\hline Structural Social Capital & .974 & 1.026 \\
Relational Social Capital & .668 & 1.497 \\
Cognitive Social Capital & .662 & 1.511
\end{tabular}

Source: Survey data, 2020

The second step in the structural model evaluation involves examining the significance of the hypothesized relationships. First, PLS algorithm was conducted to assess the path coefficients using the path weighting scheme, and then it was identified the significance as well as the sign and the magnitude of the path coefficients. Hence, $t$-values were obtained by performing a bootstrapping procedure. The critical $t$-value for a two-tailed test is 1.96 at a 0.05 significance level (Hair et al., 2011).

Table 06: Path Coefficients and Significance levels (T-Values)

\begin{tabular}{lllll}
\hline Hypothesis & Relationship & Beta & T Statistics & Decision \\
\hline H3 & CSC -> FP & 0.565 & $7.559^{\star \star *}$ & Accept \\
H2 & RSC -> FP & -0.180 & $2.535^{\star * *}$ & Not Accept \\
H1 & SSC -> FP & 0.165 & $1.965^{\star \star *}$ & Accept \\
\hline
\end{tabular}

Note: ${ }^{* * *} \mathrm{P}>0.01$

Source: Survey Data, 2020

Next, the study assessed the significance of the path coefficients using $\beta$ value and t-statistics. Given both paths' coefficients and t-statistics, Table 6 shows that all the hypothetical relationships were significant. Given that, the results of the paths towards the firm performance demonstrated that CSC, SSC, and RSC were significant at 1 percent $(p<0.01)$ (Figure 2).

The results show that $28 \%$ of the variation of business performance can be explained by social capital $\left(R^{2}\right)$. Thus, social capital shows moderate explanatory power on firm performance. The effect size of the predictive variables $\mathrm{f}^{2}$ as well as $\mathrm{Q}^{2}(>0$.) of the model variable has been evaluated and the large effect size $(0.198>0)$ depicted by the calculations hence, social capital can be affected largely on performance of SEs. Thus, the goodness of fit of the model is suitable for the predictions. 


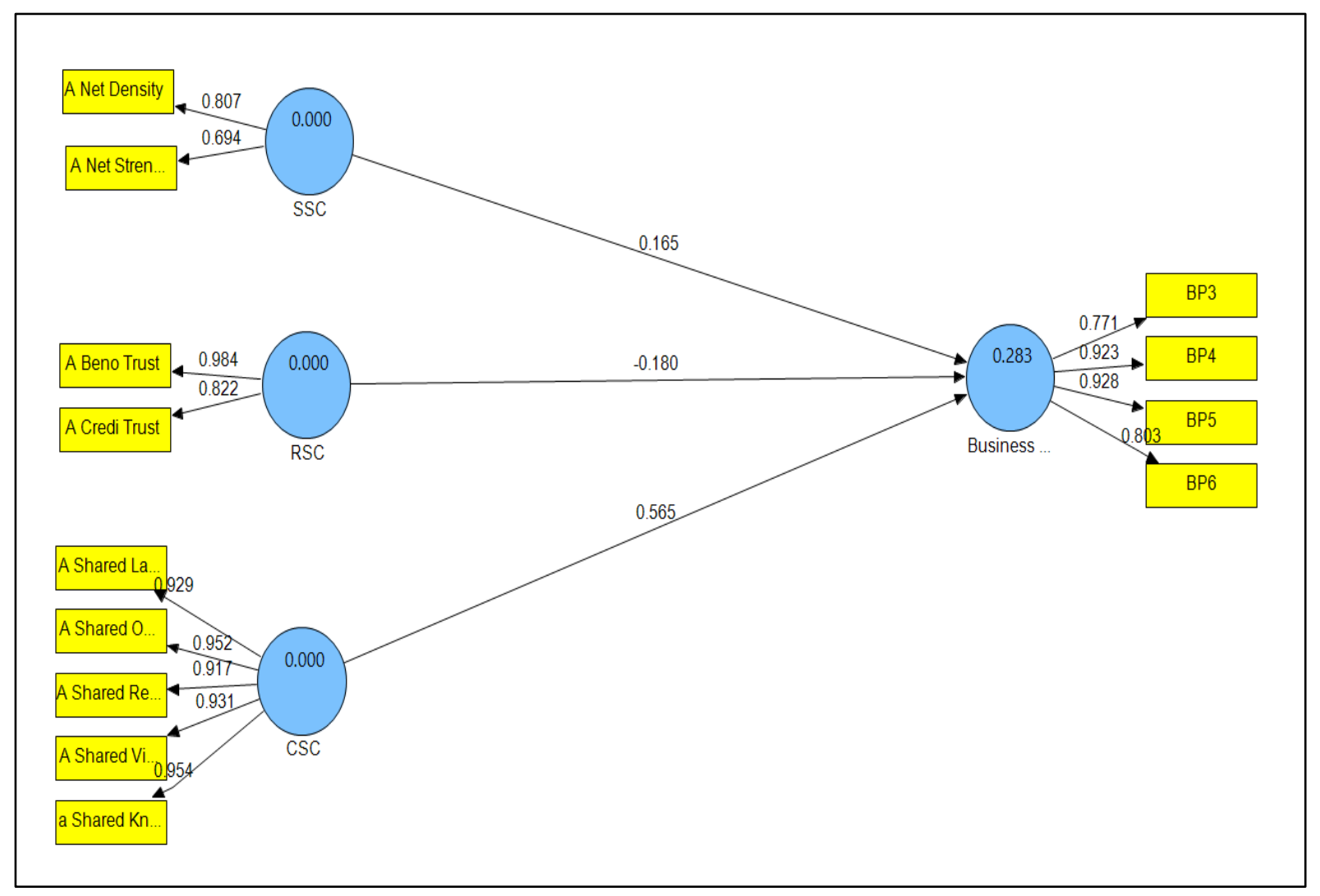

Figure 2: R-Square

\section{Discussion}

As expected, the study found that structural social capital had a positive impact on the firm performance of SEs. Table 6 shows that the structural social capital of the owner has a significant impact on firm performance $(\beta=0.165$ or 16.5 percent and $t$-value $=1.965$ ) supporting hypothesis $H 1$. The businesses are well aware of each other, share strong business networks among them and they maintain regular interactions with one another and they prefer to share whatever they know among them. The finding is consistent with Okello (2017) who find business networking as an effective low-cost marketing method for developing sales, opportunities, and contacts, based on referrals and introductions - either face-to-face at meetings and gatherings, or by other contact methods such as phone, email, and increasingly social and business networking websites. The findings also support Kipchirchir (2014) who shows different relationships between the social capital variables and the indicators of growth in Nairobi.

The results further reveal that the relational social capital could show a negative significant impact on firm performance $(\beta=-0.180$ or 18 percent and $t$-value $=2.535)$ of SEs in Sri Lanka hence, $\mathrm{H} 2$ that expect a positive relation between relational social capital and business performance is not accepted. The strong trust by the customers in the firms and favorable work environment along with good relationships among employees, management, and suppliers might not always be affected by the performance positively. When the owners maintain a robust relationship with social networks or trust with them, they are attracting customers by selling goods on a credit basis, hence, firms will lose money as a result of increasing bad debts. Instead, owners pay their attention and their time for maintaining their social network, thereby less attention to the business. Thus, interpersonal trust is affected by firm performance negatively. However, Mark, William, \& James (2009) show that the companies that have high interpersonal trust between interested parties of the organization increase the performance of the organization and the value of the activities which are done by the other parties which is not supported by this study. Soesanto \& Setiadi (2017) report that the relational capital can move the innovation of products that are the entrepreneurship capital of SMEs of furniture in Jepara, where this product innovativeness will encourage SMEs furniture to create innovative products that can improve the performance of the company's products which is not 
confirmed by this study in Sri Lankan context. The results contradict the findings of Pratono (2018) that show a positive relationship with firm performance.

As expected, the cognitive social capital had a significant positive impact on the performance of SEs ( $\beta=$ 0.565 or 56.5 percent and $t$-value $=7.559$ ) supporting hypothesis $\mathrm{H} 3$. This is because the owners of SEs share resources, opportunities with members of the social network they can achieve success together with others. Besides, if they use a common language that can be understandable by each of the social networks, they can easily exchange information and opportunities immensely useful to their businesses. This confirms the findings of Ozigi (2017) who reports that the cognitive social capital plays a significant role to get a business advantage better than competitors and to generate revenue and the overall business performance.

Overall, the study confirms that the social capital has a significant and positive relationship with SEs performance in Sri Lanka, implying the stronger is the network ties and the higher is the social understanding among the internal and external people in the network, the greater will be the firm performance through cost reduction and competitive advantage. Structural social capital also has a strong relationship with revenue drive and competitive advantage that results in an expanded revenue. The cognitive social capital is a key player in enhancing business activities and revenue generation through a business advantage over competitors sharing a common vision of the business. Thus, the study supports the findings of Agyapong, Agyapong, \& Poku (2017).

\section{Conclusion}

The objective of the study was to investigate the effect of social capital on the firm performance of SEs in the manufacturing sector in Sri Lanka. A structured questionnaire was administered among owners/managers of SEs to collect data and analyzed using SMART PLS. The social capital was measured as three pillars, namely, structural social capital, relational social capital, and cognitive social capital. The structural social capital which is measured by network size, density, and network ties had a positive impact on the performance of SEs. This implies that most of the owners/managers in SEs are likely to take part in social organizations like business clubs, though employees prefer more on network diversity. Thus, it is confirmed that the increased customer network size had positively impacted on sales volumes of the firms, hence a higher level of business performance.

The relational social capital is measured using interpersonal trust; hence the interpersonal trust is strong, profound, or close ties between more people in the network that enhance the firm's products and sales. The strong interactions among the network build relational capital that can be more easily accessed to information and resources in the network to enhance success while creating and upgrading the values and norms of the social capital.

As expected, the cognitive social capital revealed a positive significant impact on the firm performance of SEs. Most of the firms share the same business goals and values with their key suppliers and they also more likely to share expert knowledge and resources with others by keeping much care for what their customers need. Moreover, they do have a high level of shared emotional connection with the employees and among employees of the SEs.

The findings will be useful for the owners of the SEs and they should reserve time to participate in social associations such as business clubs and build relationships between members of the network and join the network to enhance their profits. Alternatively, they should make a comfortable atmosphere in the organization to meet each other thereby building up a good relationship with employees of the firm, hence the workers would build close ties with the network, work with each other by sharing knowledge, information, and resources. The negative impact of relational social capital on business performance guides the managers to maintain a high level of trust between the firm and customers, suppliers, and employees, and other related parties to the business paying more attention to increase both sales and profits of the firms. And also, proper care should be taken to minimize the relationship between people who impact adversely on operations of the businesses. The positive relation between cognitive social capital and performance will give practical implications for the owners of the SEs who should share their knowledge, opportunities, and resources with their suppliers, customers as well as employees of the organization so 
that they should try to share their goals and achieve success together parties who are related and interested to the business.

The study recommends that managers of SEs should build and increase their human and social capital to get access to resources from their association or network groupings to achieve competitive advantage. Managers must also improve their dynamic capabilities in the area of training, developing standards, and strategic business planning to enhance their performance. SEs should ensure effective communication with their network channels that must be established to provide reliable, hasty, and timely information in accessing the needed resources to survive in a competitive business environment generating higher profits.

\section{References}

1. Abban, R., Omta, S.W.F., Aheto, J. B. K. \& Scholten, V. E. (2013). "Connecting the dots: A multiple case study of the network relationships of small and medium-sized enterprises (SMEs) in the nontraditional agricultural export (NTAE) sector of Ghana", African Journal of Economic and Management Studies, 4(1), 74 - 94. https://doi.org/10.1108/20400701311303168

2. Adler, P. S., \& Kwon, S. W. (2002). Social capital: Prospects for a new concept. The Academy of Management Review, 27(1), 17. https://doi.org/10.5465/amr.2002.5922314

3. Agyapong, F.O., Agyapong, A., Poku, K. (2017). Nexus between social capital and performance of micro and small firms in an emerging economy: the mediating role of activities. Int. J. Hosp. Manag. 51, 42-55. https://doi.org/10.1080/23311975.2017.1309784

4. Aladwani, A.M. (2002). An integrated performance model of information systems projects. J. Manag. Inf. Syst., 19 (1), 185-210. https://doi.org/10.1080/07421222.2002.11045709

5. Arregle, J., Michael, A., Hitt, D., Sirmon, G., \& Philippe, V. (2007). "The development of organizational social capital: Attributes of family firms." Journal of management studies, 44(1), 73-95. https://doi.org/10.1111/j.1467-6486.2007.00665.x

6. Aslam, M.M.H., Shahzad, K., Syed, A.R., \& Ramish, A. (2013). Social Capital and Knowledge Sharing as Determinants of Academic Performance. Journal of Behavioral and Applied Management: https://www.researchgate.net/publication/260594403

7. Babaei, H., Gill, S.S., \& Ahmad, N. (2012). Bonding, bridging and linking social capital and psychological empowerment among squatter settlements in Tehran, Iran. Journal of Basic and Applied Scientific Research. (JBASR), 2(2), 109-115.

8. Batjargal, B. (2003). Social capital and entrepreneurial performance in Russia: a longitudinal study. Organ. Stud. 24 (4), 535-556. https://doi.org/10.1177/0170840603024004002

9. Batjargal, B. (2005). "Entrepreneurial versatility, resources and firm performance in Russia: A panel study". International Journal of Entrepreneurship and Innovation Management. (5), 3/4, 284-297. https://doi.org/10.1504/IJEIM.2005.006530

10. Bhagavatula, S., Elfring, T., van Tilburg, A., \& Van de Bunt, G.G. (2010). How social and human capital influence opportunity recognition and resource mobilization in India's handloom industry. J. Bus. Ventur. 25, 245-260. https://doi.org/10.1016/j.jbusvent.2008.10.006

11. Bhagavatula, S. (2009). Weaving social networks performance of small rural firms in India as an outcome of entrepreneurs' social and human capital. PhD Dissertation, Visakhapatnam University, India.

12. Bourdieu, P. (1983). Forms of capital. In J. C. Richards (Ed.), Handbook of theory and research for the sociology of education, New York, NY: Greenwood Press, 46-59.

13. Bouzdine, T., \& Lorgnier, M. (2004). The role of social capital within business networks: analysis of structural and relational arguments. Fifth European Conference on Organisational Knowledge, learning and Capabilities. Innsbruck, Austria. 
14. Bradley, S.W., McMullen, J.S., Artz, K., \& Simiyu, E.M. (2012). Capital is not enough: innovation in developing economies. J. Manag. Stud. 49 (4), 684-717. https://doi.org/10.1111/j.14676486.2012.01043.x

15. Brink, T. (2011). What connections in networks of private entrepreneurs are related to growth? J. Depopulation Rural Dev. Stud. 11, 57-82.

16. Burt, R.S. (2000). "The network structure of social capital". Research in Organizational Behavior, 22, 345 - 423. https://doi.org/10.1016/S0191-3085(00)22009-1

17. Cantner, U., \& Stuetzer, M. (2010). The use and effect of social capital in new venture creation-Solo Entrepreneurs vs. New Venture Teams. Jena Econ. Res. Pap.

18. Celestini, J., Gavronski, \& Kaynak, H. (2013). The relationship between social capital and operational performance. https://www.semanticscholar.org/paper/The-relationship-between-social-capitaland-Celestini-Gavronski/dc96d574ad405a2b2cc12509cf5843bb1865b8a3

19. Chang, K., Wong, J., Li, Y., Lin, Y., \& Chen, H. (2011a). External social capital and information systems development team flexibility. Inf. Softw. Technol. 53, 592-600. https://doi.org/10.1016/j.infsof.2011.01.007

20. Chow, W. S., \& Chan, L. S. (2008). "Social network, social trust and shared goals in organizational knowledge sharing". Information \& Management, 45(7), $458 \quad-465$ https://doi.org/10.1016/j.im.2008.06.007

21. Clarke, R., Chandra, R., \& Machado, M. (2016). SMEs and social capital: exploring the Brazilian context. Eur. Bus. Rev. 28 (1), 2-20. https://doi.org/10.1108/EBR-03-2013-0065

22. Coleman, \& James S. (1990). Foundations of Social Theory (Harvard University Press, Cambridge, MA).

23. Coleman, J. S. (1988). Social capital in the creation of human capital. The American Journal of Sociology, 94(Supplement: Organizations and Institutions: Sociological and Economic Approaches to the Analysis of Structure), S95-S120. https://doi.org/10.1086/228943

24. Coleman, J. S. (1990). Foundations of social theory. Cambridge, MA: Harvard University Press.

25. Dai, W.D., Mao, Z.E., Zhao, X.R., \& Mattila, A.S. (2015). How does social capital influence the hospitality firm's financial performance? The moderating role of entrepreneurial activities. Int. J. Hosp. Manag. 51, 42-55. https://doi.org/10.1016/j.ijhm.2015.08.011

26. Fafchamps, M., \& Minten, B. (2002). Returns to social network capital among traders. Oxf. Econ. Pap. 54, 173. https://doi.org/10.1093/oep/54.2.173

27. Felicio, J.A., Couto, E., \& Caiado, J. (2014). Human capital, social capital and organizational performance. Manag. Decis. 52 (2), 350-364. https://doi.org/10.1108/MD-04-2013-0260

28. Florin, J., Lubatkin, M., \& Schulze, W. (2003). A social capital model of high-growth ventures. Academy of Management Journal, 46, 374-384. https://doi.org/10.2307/30040630.

29. Geletkanycz, M.A, \& Hambrick, D.C. (1997). The external ties of top executives: Implications for strategic choice and performance. Administrative Science Quarterly 42, 654-681. https://doi.org/10.2307/2393653

30. Granovetter, M. (1973). The strength of weak ties. American Journal of Sociology, 78(6). https://doi.org/10.1086/225469

31. Granovetter, M. (1983). The strength of weak ties: A network theory revisited. Sociological theory, 201-233. https://doi.org/10.2307/202051

32. Hair, J.F., Ringle, C.M., Sarstedt, M. (2011). PLS-SEM: Indeed, a silver bullet. Journal of Marketing theory and Practice, 19(2), 139-152. https://doi.org/10.2753/MTP1069-6679190202

33. Hitt M. A., Uklee, H, \& Yucel, E. (2002). The importance of social capital to the management of multinational enterprises: Relational networks among Asian and Western firms. Asia Pacific Journal of Management, 19, 353-372. https://doi.org/10.1023/A:1016247920461 
34. Jones, G. R., \& George, J. M. (1998). The experience and evolution of trust: Implications for cooperation and teamwork. Academy of Management Review, 23, 531-546. https://doi.org/10.5465/amr.1998.926625

35. Leana, C. R., \& Pil, F. K. (2006). Social capital and organizational performance: Evidence from urban public schools. Organization Science, 17, 353-366. https://doi.org/10.1287/orsc.1060.0191.

36. Kipchirchir, E. (2014). The influence of social capital on the performance if SMEs in Nairobi County, Kenya. Unpublished MBA Thesis. University of Nairobi.

37. Kline, B. R. (2011). Principles and Practice of Structural Equation Modeling. Third Edition, The Guilford Press, New York.

38. Le Van, C., Nguyen, A.N., Nguyen, N.M., \& Simioni, M. (2018). Growth strategy with social capital, human capital and physical capital theory and evidence: The case of Vietnam. Journal of Public Economic Theory, 20(5), 768-787. https://doi.org/10.1111/jpet.12305

39. Mark, B. C., William , T. H., \& James, B. M. (2009). Critizenship Behavoir and the creation of social capital in Organization. Academy of Management Review,27 (4).

40. Misztal, B. (1996). Trust in modern societies. Cambridge: Polity Press.

41. Mishira, A. K. (1996). Organizational responses to crisis: the centrality of trust. In: Kramer, R. M., \& Tyler, T. Trust in Organizations: frontiers of theory and research. Newbury Park: Sage, 261-287. https://doi.org/10.4135/9781452243610.n13

42. Muniady, R. A., Mamun, A. A., Mohamad, M. R., Permarupan, P. Y., \& Zainol, N. R. B. (2015). The Effect of cognitive and relational social capital on structural social capital and micro-enterprise performance. SAGE Open, 5(4), 1-9. http://doi.org/10.1177/2158244015611187.

43. Nahapiet, J. \& Ghoshal, S. (1998). "Social capital, intellectual capital, and the organizational advantage". Academy of Management Review, 23(2), 242 - 266. https://doi.org/10.5465/amr.1998.533225

44. Ndofor, H.A., \& Priem, R. (2011). Immigrant entrepreneurs, the ethnic enclave strategy, and venture performance. J. Manag. 37, 790-818. https://doi.org/10.1177/0149206309345020

45. Okello, O.R. (2017). The effect of social capital on the growth of medium enterprises in Kenya. Dissertation. Retrieved: http://erepo.usiu.ac.ke/handle/11732/3458

46. Ozigi,O. (2017). Social capital and financial performance of small and medium scale enterprises. Journal of Advanced Research in Business and Management Studies 10(1), 18-27.

47. Patel, P.C., \& Terjesen, S. (2011). Complementary effects of network range and tie strength in enhancing transnational venture performance. Strateg. Entrepren. J. 5, 58-80. https://doi.org/10.1002/sej.107

48. Pearson, A., Carr, J. C., \& Shaw, J. C. (2008). Toward a theory of familiness: A social capital perspective. Entrepreneurship Theory and Practice, 32, 949-969. https://doi.org/10.1111/etap.2008.32.issue-6. https://doi.org/10.1111/j.1540-6520.2008.00265.x

49. Pratono, A.H. (2018). From social network to firm performance: the mediating effect of trust, selling capability and pricing capability. Manag. Res. Rev. 41. https://doi.org/10.1108/MRR-03-2017-0080

50. Premaratne, S. P. (2002). Entrepreneurial networks and small business development: The Case of Sri Lanka. PhD Dissertation, Eindhoven: Eindhoven University of Technology.

51. Priyanath, H. M. S., \& Premarathne, S. P. (2015). Effect of social capital on transaction cost: A multiple case study of small enterprises in Sri Lanka. International Journal of Arts and Commerce, 4(4), 127138.

52. Putnam, R. D. (1995). 'Bowling Alone: America's Declining Social Capital'. Journal of Democracy 6(1), 65-78. https://doi.org/10.1353/jod.1995.0002 
53. Rooks, R., Szirmai, A., \& Sserwanga, A. (2009). The interplay of Human and social capital in entrepreneurship in developing countries (Research Paper N0.). UNU-WIDER, World Institute for Development Economics Research, United Nations University.

54. Soesanto, H. \& Setiadi. (2017). Social capital dimensions in SMS manufacturing firms in central Java: Do They Matter? International Journal of Civil Engineering and Technology, 8(11), 1059-1069.

55. Stam, W., Arzlanian, S., \& Elfring, T. (2014). Social capital of entrepreneurs and small firm performance: a meta-analysis of contextual and methodological moderators. J. Bus. Ventur, 29, 152 173. https://doi.org/10.1016/j.jbusvent.2013.01.002

56. Stone, W. (2001). Measuring social capital: towards a theoretically informed measurement framework for researching social capital in family and community life. Australian Institute of Family Studies, Melbourne Research Paper 24.

57. Tsai, W \& Ghoshal, S. (1998). "Social capital and value creation: the role of intra firm networks". The Academy of Management Journal, 41(4), 464 - 476. https://doi.org/10.2307/257085

58. Uzzi, B. (1996). "The sources and consequences of embeddedness for the economic performance of organization: the network effect". American Sociological Review, 61, 674 -98. https://doi.org/10.2307/2096399

59. Weick, K. E. (1995). Sensemaking in organizations. Thousand Oaks, CA: SAGE 